\title{
10 ANOS DE ASSALTO POÉTICO \\ EXPERIÊNCIAS COM POESIA FALADA
}

João Pedro Fagerlande é poeta, performer e gestor da Poesia Viral Produções. Doutorando e mestre em Literatura Brasileira pela UFRJ. Coordena com Eliza Morenno o projeto "Grandes Poetas Brasileiros", um programa de incentivo à leitura em escolas e bibliotecas municipais do Rio de Janeiro, com patrocínio da Secretaria Municipal de Cultura. Realiza espetáculos e oficinas de poesia falada.

Email: joaofager@gmail.com

\section{Resumo}

Este relato descreve a história do Assalto Poético, grupo de poesia falada que surgiu em 2004 no Rio de Janeiro e atuou até 2014. Criado nos saraus da Faculdade de Letras da UFRJ, o Assalto saiu para o mundo invadindo bares e restaurantes do Rio e Niterói. Circulou também por espaços como praças, escolas, bibliotecas e empresas, recebendo em 2012 o Prêmio FUNARTE Artes na Rua.

\begin{abstract}
This is the history of Assalto Poético, a group of poetry speakers founded in 2004 in Rio de Janeiro and acted until 2014. Created in the slams of UFRJ, in Letters, Assalto Poético run out the world entering restaurants, bars, and also speaking poetry in squares, schools, libraries, enterpreises, malls, receiving in 2012 the FUNARTE Street Art Premium.
\end{abstract}

Eu entrei em 2004 para a Faculdade de Letras da UFRJ, no Fundão, e lá descobri uma coisa que me marcaria para sempre: os saraus de poesia. Os estudantes se reuniam no pátio central e falavam no microfone poemas de sua autoria ou de seus autores favoritos.

Havia na faculdade o Movimento Cultural Letras pelas Letras, um grupo de estudantes que promovia cineclube, jornal literário, debates políticos, shows, viagens ao Fórum Social Mundial e outros encontros. Eram eles que faziam os saraus.

Toda quinta feira, às 12:47 (como constava nos cartazes) os poemas ganhavam voz, na hora da saída dos alunos. Uns passavam rápido, ouviam apenas um poema, outros não perdiam um sarau sequer. $O$ fato é que havia sempre uns 30, 40 estudantes ali no pátio experimentando a palavra juntos. Às vezes vinham professores, outras vezes convidamos poetas de fora ${ }^{1}$. E muitos aproveitavam para vender seus livretos artesanais, pois já o faziam pelas ruas do Rio e nas viagens estudantis.

Um grupo desses mais assíduos nos saraus começou a achar que falar poesia ali, dentro da Faculdade de Letras, para alunos que já gostavam de literatura, estava fácil demais. Era necessário sair de casa, ganhar a cidade, chegar nos cidadãos que não estavam habituados a esse tipo de atividade.

Mas como? De que maneira a gente poderia recitar poesia para as pessoas na rua?

- Um assalto poético!

Um assalto poético. O Rio de Janeiro era famoso pela violência, os noticiários não paravam de bombardear histórias de tiroteios, então o nome fazia sentido naquele contexto. Chegar de assalto no cidadão comum e em vez de roubar ou ferir, oferecer um poema. Todos aprovamos. Éramos quatro nesse momento, eu, Cadu Vaz, Genaro Neto e

\footnotetext{
${ }^{1}$ Dentre os professores, a pessoa mais presente era Cinda Gonda. Mano Melo e Claufe Rodrigues vieram como poetas visitantes. Frequentavam também os saraus, além dos que viriam a formar o Assalto Poético, os estudantes: Camila Duarte, Celme de Alcantara, Diego Rezende, Gregory Costa, Hugo Fragoso, Janda Montenegro, Julieta Al, Patricia Bastos, Rafael Nunes, Renato Pardal e outros. 
Julia Pastore. Nós entraríamos em bares e restaurantes para falar nossos poemas e ao fim ofereceríamos um livreto do grupo, que as pessoas poderiam adquirir com uma contribuição voluntária.

Cadu era o melhor na diagramação, tinha certa experiência como designer e coube a ele montar nosso livreto. Cada um selecionou três poemas próprios.

O livreto ficou bom em comparação ao material que circulava pelo Rio na época. Com capa vermelha ou amarela (eram duas versões), design arrojado, urbano. $\mathrm{O}$ papel reciclado dava uma textura melhor que o branco. E nós quatro montamos artesanalmente os livretos na minha casa, dobrando, grampeando... Foram mais de mil.

Mas faltava uma abertura para o Assalto. Como a gente chegaria nas pessoas? Não dava para chegar falando um poema assim do nada, o ouvinte ia achar que a gente era maluco. Precisava de uma abertura para dar sentido à ação, fazendo o público ouvir o que a gente tinha para dizer.

- João, por que você não escreve um poema?

No mesmo dia em que o Cadu me sugeriu, ao chegar em casa, à noite, eu escrevi:

\author{
Ouvidos ao alto! \\ Não se movam \\ nem pronunciem sequer uma palavra \\ nós viemos roubar a atenção de vocês \\ qualquer tentativa de reação será inútil \\ nossa garganta já está engatilhada \\ e apontada \\ para suas míseras orelhas \\ a metralhadora de versos é fatal \\ e a vocês não resta escolha \\ entreguem suas lágrimas \\ seus sorrisos \\ suas máscaras \\ e suas falsas sanidades \\ que isso aqui é um Assalto Poético
}

No dia seguinte, na faculdade, eu falei o poema para eles. Todos gostaram, então a gente já tinha resolvido a abertura. Combinamos que o figurino seria terno para os homens e vestido preto elegante para a Julia. Levaríamos os livretos numa maleta executiva preta, que tinha pertencido ao meu avô. Agora tudo estava pronto, só faltava agir.

Achamos que sexta feira seria um dia mais apropriado para fazer o Assalto, porque teria mais gente nos bares e restaurantes. Combinamos de nos encontrar na casa da minha mãe, onde eu morava, no Jardim Botânico. Lá tomamos umas doses, fizemos uma fumaça e saímos por volta das $21 \mathrm{~h}$. Todos no meu carro, indo para nossa primeira parada, o Bar Lagoa. 
O Bar Lagoa, para quem não conhece, é um bar/restaurante tradicional do Rio, de frente para a Lagoa Rodrigo de Freitas, famoso pelo mal humor de seus garçons. Lá com certeza estaria cheio, tinha espaço para a gente circular, passar pelas mesas, e assim foi o lugar escolhido para o primeiro Assalto.

Parei o carro bem em frente, descemos e pegamos uma mesa. O garçom veio falar com a gente e pedimos uma rodada de chope. Conversávamos tomando o chope, sem saber exatamente como dar início. Quem seria o primeiro a falar? Ninguém queria ir. Pedimos mais uma rodada, fumamos uns cigarros, até que eu tomei a decisão. Ao terminar o último gole do chope, levantei com os meus joelhos tremendo e gritei para todo o restaurante:

- Ouvidos ao alto!

Eu estava morrendo de medo, num impulso inconsequente que dava um prazer enorme, porque era a ruptura de um clima geral do ambiente, todos ficavam quietos enquanto a gente falava os poemas. Era uma adrenalina, uma sensação de poder, de conexão com as pessoas ali presentes. Falamos dois poemas; quem não falava passava de mesa em mesa deixando os livretos e depois voltava pedindo uma contribuição. Algumas pessoas acharam que era um assalto de verdade, se trancaram nos banheiros, depois vieram falar com a gente. No fim todos gostaram da brincadeira, vendemos muitos livretos. Ouvimos ainda uma coisa que nenhum dos quatro conseguiu esquecer.

- Vocês vieram assaltar logo aqui, onde vem a nata da crítica cult!

Rimos muito. A nata da crítica cult!!!

E assim começaram os assaltos. Eram em torno de oito por noite, três a quatro vezes por semana. Ficamos neste esquema uns dois meses e meio, foi a primeira fase do Assalto. A gente fazia nos bares e restaurantes do Rio, muito em Santa Teresa, Copacabana, Glória, Lapa, Vila Isabel, Tijuca... Fazíamos também em Niterói, onde a Julia morava.

Uma vez, em Niterói, um cara chamou a gente depois do Assalto. Ele estava sentado numa mesa no canto do restaurante e, meio bêbado, sacou uma arma. Ele disse, meio brincando, meio sério, para a gente tomar cuidado com essa história de assalto. Ficamos preocupados com isso, com medo de que algum dia um doido sacasse uma arma e atirasse. Até porque já tinha acontecido de pessoas se trancarem no banheiro, se esconderem embaixo da mesa, pensando que era um assalto de verdade.

Mas foi também na mesma época que uma série de contratempos começaram a correr dentro do grupo. Até que se chegou à decisão de terminarem os assaltos poéticos. Lembro que nossa última reunião foi próxima à biblioteca da Letras, os quatro sentados no chão.

E foi a biblioteca, dois anos depois, que nos trouxe de volta à vida. Rosangela Val, a nova diretora da Biblioteca da Letras, recém-chegada do Maranhão, chamou os poetas da Faculdade para apresentações na Bienal do Livro, no estande do SESC Rio / Jornal O Globo. Nas reuniões, em que estávamos eu e Julia, surgiu a ideia de retomarmos o projeto do Assalto. E retomamos.

As apresentações foram realizadas por três grupos de poesia falada da Faculdade, o Assalto Poético, a Repartição da Flor, o Cante Poema, além do grupo de 
teatro de outro aluno poeta, Jessé Castilho. Foi formada também a Roda de Letras, coletivo que reunia integrantes de todos os grupos, e eu assumi sua direção.

As apresentações na Bienal foram um sucesso e logo fomos convidados para o Festival de Inverno SESC Rio. Assalto Poético e Repartição da Flor se apresentaram em Petrópolis, Teresópolis e Friburgo. Como ganhávamos cachês, não era mais necessário vender os livretos (mas a gente sempre levava, no caso de alguém pedir). Era muito luxo, a gente recitando poesia no clima da serra!

Com o bom resultado do Festival de Inverno, fomos chamados para vários trabalhos nos SESCs. As bibliotecas adoravam a gente, fazíamos assaltos também em praças, shoppings, empresas de telemarketing (!), até em supermercados. O SESC foi muito importante para nosso crescimento.

E a gente se apresentava em tudo quanto era lugar, tanto com cachê ou de graça. A ideia era que "trabalho chama trabalho", então quanto mais a gente se apresentasse mais oportunidades iriam surgir. Queríamos viver disso, seguir um caminho profissional. No fundo, isso já estava acontecendo.

Fizemos uns trabalhos também no Roxinho, um teatro da UFRJ localizado no Centro de Ciências Matemáticas e da Natureza, no Fundão. Era um teatro antigo, com muita história, que havia sido reformado e agora contava com ótima estrutura, bons camarins, iluminação, sistema de som, poltronas confortáveis, enfim, um teatro incrível à disposição dos estudantes. Havia uma programação com apresentações de alunos da universidade - a "Prata da Casa" -, mas também contratavam artistas externos para apresentações gratuitas. Passaram por lá Yamandu Costa, Geraldo Azevedo, Luis Melodia, e muitos outros.

Um dia o produtor do Roxinho ligou para gente, chamando para fazer a abertura do show do Arlindo Costa. Arlindo, famoso sambista saído do Fundo de Quintal, ia com certeza atrair muitos estudantes, seria um showzasso, e era de graça. Como não aceitaríamos falar poesia para uma multidão de estudantes, e ainda por cima em nossa própria casa?

Mas ao mesmo tempo lembramos o que aconteceu com o Carlinhos Brown no Rock in Rio 3. Eu estava lá e vi a multidão lançar garrafas de plástico vazias sobre o cantor no meio do show. Era um festival de rock, a galera estava lá para assistir Guns and Roses e outras bandas mais pesadas, aí entra o cara cantando outro tipo de música. Não corresponder à expectativa de uma multidão - ainda mais de roqueiros - é um risco muito alto.

Pensamos nisso porque, afinal de contas, era um show de samba. Ninguém estava lá para ouvir poesia. Por isso a gente montou um set mais curto, com apenas 10 minutos, com poemas bem comunicativos, com humor também. A gente terminaria com "A poesia", do Gullar, um poema que tínhamos trabalhado muito, era nosso melhor número.

No dia, um pouco antes de entrar em cena, olhamos por trás da cortina. Tudo lotado! Tinha gente sentada no chão, nos corredores, muitos em pé lá atrás. Era um burburinho só. O produtor veio falar com a gente:

- 5 minutos. 
A adrenalina estava no pico. Eu e Julia nos abraçamos, nos olhamos nos olhos e sorrimos. Estávamos felizes para caramba, era o nosso dia. Fizemos os últimos aquecimentos e partimos para a cena.

Mas foi só a gente pisar no palco para o cara da mesa de som soltar um samba em alto volume nas caixas do teatro. Aquilo definitivamente não estava no script! Sem microfone, não tínhamos como sobrepor o samba só com nossa voz.

Devia ser uma cena bem engraçada para o público. Imagina, você está lá para assistir ao show do Arlindo Cruz, marcado para 13h, e às 13:30 entram dois artistas com um samba tocando no fundo, eles tentando falar alguma coisa que você não consegue entender.

A gente fez sinal para o cara cortar o som da caixa, o que ele demorou quase um minuto para fazer. Tínhamos perdido a nossa abertura, então partimos para o poema seguinte. O público com certeza estava achando aquilo tudo muito esquisito. Tivemos certeza disso quando começaram as vaias.

- Ar-lin-do! Ar-lin-do! - pedia a multidão.

A situação estava tensa. Quando recitávamos "A poesia", nosso grande número, dei um pulo do palco para a plateia, para tentar conquistar a atenção do público. Mas foi um gesto impulsivo, não olhei para baixo antes de pular, só quando já estava no ar percebi que tudo ali embaixo estava escuro, a luz não chegava, eu não vi a altura.

Consegui cair em pé, mas acabei fraturando o tornozelo (o que descobri depois, no raio X). Continuamos falando o poema como se nada tivesse acontecido. Voltei para o palco, dei minhas falas e, esperando as falas de Julia, veio um silêncio. Eu estranhei, olhei para o lado e vi que ela tinha saído para a coxia. Ou seja, eu estava sozinho no palco do Roxinho, com uma multidão me vaiando e pedindo a presença do artista principal. Uma situação miserável.

Aquilo me gerou uma energia extraordinária, um instinto de sobrevivência absurdo. Pulei todo o texto e fui direto para o final, vociferando para a plateia, com dedo em riste:

- Poesia! Paixão! Revolução! - que eram os versos finais do poema. E é claro que eu embuti um palavrão bem cabeludo no final, para dar ênfase à mensagem.

A plateia subitamente silenciou. Ficaram todos quietos por pouquíssimos segundos e a situação de vaia, num piscar de olhos, se transformou em êxtase geral. Naquele momento eu recebi a maior força de aplausos que recebi em toda minha vida. Era a multidão inteira. E o que eles estavam aplaudindo foi não o meu talento, mas o meu instinto de sobrevivência, como um rato acuado que salta e arranha a cara do gato. Eu me sentia um bicho, era uma redenção.

Quase derrubei o cavaquinho do Arlindo quando fui embora do palco.

Depois de um tempo apareceu a possibilidade de se criar uma iniciativa chamada Arte de Declamar. Junto à Sala Monteiro Lobato, da Letras, criamos um projeto de iniciação artístico e cultural com bolsas de estudo da Reitoria, para montarmos um 
grupo de teatro com foco em poesia e elaborarmos metodologias para oficina de poesia falada em escolas. Criamos o grupo Metaforia em 2008, em que eu assumi a direção e a Julia a preparação vocal. Éramos sete alunos ${ }^{2}$. Com o Metaforia montamos o espetáculo Estopim: 68 em xeque, sobre os 40 anos de maio de 68. Fizemos também intervenções em espaços da UFRJ, além de oficinas para alunos de escolas públicas.

Quando acabou o projeto, apareceu uma vaga para assessor de literatura do SESC Nacional. Eu havia acabado de me formar e achei que no SESC eu poderia ampliar o âmbito dessas ações, levando os trabalhos com poesia para vários estados. Acabei sendo chamado para a vaga. Continuamos o trabalho com o Assalto, mas depois de um tempo percebi que não havia mais condições. Eu também cursava o mestrado em Literatura Brasileira na UFRJ, não havia tempo suficiente para dar conta de todas as atividades. Foi nessa época que eu saí do Assalto Poético e no meu lugar entrou a Manuela Berardo.

Mas logo que entrei no SESC percebi que o trabalho era bem diferente do que eu imaginava. Havia uma carga puxada de burocracia e não existia mais a relação direta com o público que eu tanto gostava.

Depois de um tempo pedi demissão do SESC. A Julia também não estava indo bem com a nova parceira. Foi assim que retomamos o Assalto Poético, eu e ela, desta vez com o foco totalmente destinado à sobrevivência profissional. Nós queríamos viver de poesia.

Começamos a nos organizar melhor profissionalmente. Os ensaios eram sempre acompanhados de trabalhos de produção, para vender nossas atividades. Assim conseguimos conquistar um bom mercado, falando poemas em escolas, bibliotecas, centros culturais, feiras literárias etc. Fizemos apresentações na FLIP e novamente no Festival de Inverno SESC Rio.

Nessa época a gente trabalhava com a linguagem do palhaço. Queríamos deixar claro que os assaltos eram uma brincadeira, uma subversão da violência pela graça. Fizemos um curso com a Yeda Dantas para criação de palhaços, que ajudou a construir o que viriam a ser nossos personagens, o Mandinga e a Greice Kellen.

Começamos a participar de editais para levantar fundos para um projeto maior. Até que convidamos o Marcio Libar - com quem eu tinha trabalhado no espetáculo "Drummond e Mignone: conversações" - para dirigir a gente. Eu sabia que o Assalto ia aprender muito com o Libar, que era um cara com mais de vinte anos de experiência com teatro de rua e com a linguagem do palhaço. Foi com essa ideia chave que ganhamos o Prêmio Funarte Artes na Rua pelo projeto "Assalto Poético nas ruas do Rio", com direção do Libar. Fizemos 15 intervenções em espaços públicos da cidade, passando por várias áreas, desde praias às favelas, centro e periferias.

Um dos fatores que pesou para convidar o Libar para o trabalho era o fato de ele ser um palhaço, que era também a nossa linguagem. Mas, surpresa, na primeira reunião ele degolou nossos palhaços.

- Cara, por que vocês são palhaços?

\footnotetext{
${ }^{2}$ Participavam também os estudantes Eduardo Rosal, laci Sagnori, Priscila Wandalsen, Pedro Alegre e Tiago Okasian. As orientadoras do projeto eram Cristiane Madanêlo, Georgina Martins e Rosa Gens. Revista Escrita Rua Marquês de São Vicente, 225 Gávea/RJ CEP 22451-900 Brasil Ano 2015. Número 20. ISSN 1679-6888. escrita@puc-rio.br
} 
A gente não sabia direito, lembrávamos que no passado tinham mostrado a arma para a gente, então queríamos encontrar uma forma de provar que aquilo não era um assalto de verdade. O palhaço era uma espécie de proteção.

Com os argumentos do Libar, a nossa máscara branca foi pelo ralo. Aos poucos conseguimos encontrar outra linguagem, com uma pitada clássica, meio anos 60, nas cores preto e branco. Para Julia, vestido preto de bolinhas brancas e sapatos punks; para mim, calça jeans escura, camisa branca, suspensórios, chapéu e All-star pretos. Adotamos uma linguagem mais limpa e abandonamos - mas nunca se abandona por completo - os palhaços.

Nessa mudança passamos também a usar mais a música. A Julia cantava participava de corais há alguns anos - e eu acompanhava no pandeiro. Ao repertório de poemas incluímos canções como "Carinhoso", de Pixinguinha e João de Barro, "Berimbau", de Baden Powell e Vinícius de Morais, entre outras. As músicas ajudavam a criar familiaridade com as pessoas. E continuávamos a usar o poema do Assalto nas aberturas.

Nossos antigos vícios de falar poesia também vieram abaixo. O Libar ajudou a gente a limpar a fala, tirar os exageros, buscando nossa própria voz para interpretar os poemas. Assim o Assalto Poético chegou numa nova fase, marcada especialmente pelo Prêmio Funarte.

Nesse projeto falávamos poesia para tudo quanto é tipo de gente. Porque a rua, a praça, é o espaço mais democrático que existe. Tem os ambulantes, os aposentados, as crianças, os pais e mães, a polícia, os moradores de rua, os que estão só de passagem... E falávamos poesia para todo mundo, sem restrições.

Lembro que a gente adorava o desafio de falar poemas eruditos para moradores de rua. Era Fernando Pessoa, Gregório de Matos, Vinícius, Drummond... Nossa estratégia era se aproximar deles e dizer o poema num tom absolutamente informal. Às vezes encaixávamos expressões como "Tá ligado?" ou começávamos o poema com um "Aí, meu irmão, se liga nessa", o que criava um clima de proximidade, de afetividade. Ao final eles se expressavam: "Falou e disse!!", "Esse é o cara!”. Eles sentiam o ritmo das palavras com a gente, era o maior barato.

Depois da circulação pela Funarte, fizemos muitos SESCs, escolas, uma circulação pelo Rio com patrocínio da Prefeitura ("Assalto Poético nas praças e parques do Rio - 10 anos de Assalto Poético"). Assaltamos muitas empresas, praças, shoppings, feiras e ruas pelo estado do RJ.

Lá pelo meio de 2013 eu e Julia começamos a ter divergências. Em toda relação existem divergências, mas nessa época começaram a ficar maiores, porque os projetos também estavam maiores. Nós dois queríamos coisas diferentes e o Assalto acabou deixando de se transformar, se engessando numa fôrma. Nós não ensaiávamos mais, falávamos sempre os mesmos poemas, as mesmas canções. A gente recebia muitos convites e ficou repetindo a fórmula durante um ano. Mas a pior coisa que pode acontecer a um artista é se acomodar a uma fôrma. Depois do projeto de circulação com a prefeitura do Rio, em 2014, decidimos encerrar as atividades do Assalto Poético e prosseguir nossos trabalhos separadamente. 
Mas a energia das ruas, essa poesia atravessando espaços, não vai sair da gente nunca mais.

Rio, 21 a 23 de fevereiro de 2015. 